\title{
Impact of FDI on Private Investment in the Asian and African Developing Countries: A Panel-Data Approach
}

\author{
Le Thanh TUNG*, Pham Nang THANG** \\ Received: January 16, 2020 Revised: February 9, 2020 Accepted: February 11, 2020.
}

\begin{abstract}
The paper aims to investigate the impact of foreign direct investment (FDI) on private investment with a sample having 49 developing countries in Asia (17 countries) and Africa (32 countries) during the period of 1990-2017. Unlike previous studies, we split the data into three groups for further analysis, including the Asian, African and the full-panel samples. The results confirm a crowding-in effect which shows that foreign direct investment promotes private investment on all three research samples. Besides, the lagged private investment has a positive and significant effect on itself in the next period which reflects the inertia in the trend of private investment in recipient countries. In the full-panel sample, there are some macro factors such as GDP per capita, trade openness, and electricity that also have a positive and statistically significant impact on private investment. Besides, when more deeply estimate with smaller samples, we find that trade openness and labour force have a positive and significant in Africa, on the other hand, not in Asia. However, the domestic credit variable has a negative and significant effect on private investment only in Asian developing countries. Furthermore, there is only a positive and significant impact of the electricity variable on private investment in Asia.
\end{abstract}

Keywords: FDI, Private Investment, Developing Country, Crowding-in, Crowding-out

JEL Classification Code: E22, F23, O19.

\section{Introduction}

Foreign direct investment (FDI) plays a leading role in promoting economic growth (Borensztein, Gregorio, \& Lee, 1998; Omri \& Kahouli, 2014; Ali \& Fei, 2016; Erum, Hussain, \& Yousaf, 2016) or poverty reduction (Klein, Aaron, \& Hadjimichael, 2001; Ucal, 2014) in developing countries worldwide. Besides, the other important roles of FDI are also reflected in the spread of new technologies, advanced management skills, or new business knowledge (Kobrin, 2005; Choi \& Yüce, 2016). FDI has been

*First Author and Corresponding Author. Associate Professor, Faculty of Economics and Public Management, Ho Chi Minh City Open University, Vietnam [Portal Address: 97 Vo Van Tan Street, Ward 6, District 3, Ho Chi Minh City, 700000, Vietnam] Tel: +84 02838364748. Email: tung.It@ou.edu.vn.

**Assistant Researcher, Master of Economics, Graduate School, Ho Chi Minh City Open University, Vietnam.

Email: thangpn.158e@ou.edu.vn

(c) Copyright: The Author(s)

This is an Open Access article distributed under the terms of the Creative Commons Attribution NonCommercial License (https://creativecommons.org/licenses/by-nc/4.0/) which permits unrestricted noncommercial use, distribution, and reproduction in any medium, provided the original work is properly cited. continuously increasing in recent years, with an estimated value of $\$ 671$ billion coming in developing countries in 2016 (UNCTAD, 2018). However, as an external financial flow, there has been much debate about the real impacts of FDI inflows on macroeconomic variables in host economies. In particular, FDI is said to be a cause of increasing environmental pollution (Cole \& Elliott, 2005; Wang, Gu, Tse, \& Yim, 2013), making inequality (Figini \& Gorg, 2011; Herzer \& Nunnenkamp, 2013).

Besides, after timing periods of attracting FDI, many developing countries have also successfully developed the private sector, as well as private investment, has gradually grown. In the context of declining FDI in the world economic recession periods, private investment has become an important driving force for economic recovery in many developing countries. Therefore, the real interaction between FDI and private investment is always an important issue which receives much concerning of policymakers from the host countries worldwide (for example, Kim \& Seo, 2003; Agosin \& Machado, 2005; Ndikumana \& Verick, 2008; Adams, 2009; Wu, Sun, \& Li, 2010; Al-Sadig, 2013; Djokoto, Srofenyoh, \& Gidiglo, 
2013; Omri \& Kahouli, 2014; Szkorupová, 2015; Tung, 2019; Jude, 2019).

In recent years, there are some studies focusing on the effect of FDI on private investment, however, their results are contradictory or arguments. Firstly, FDI positively affects (known as a crowding-in effect phenomenon) on private investment or private capital in receiving countries (Xu \& Wang, 2007; Ndikumana \& Verick, 2008; Ang, 2009; Wang, 2010; Wu, Sun, \& Li, 2010; Al-Sadig, 2013; Djokoto, Srofenyoh, \& Gidiglo, 2013; Omri \& Kahouli, 2014; Tung, 2019). Secondly, on the other hand, there are some previous results confirm a crowding-out effect which implies FDI negatively affects private investment in host countries (Aitken \& Harrison, 1999; Agosin \& Machado, 2005; Adams, 2009; Szkorupová, 2015). Thirdly, we have some results suggest that FDI has both crowding-in and crowding-out effect (e.g., Fry, 1993) or non-impact on private investment and also reject both crowding-in and crowding-out effect (e.g., Saglam \& Yalta, 2011).

These above contradictory results have made much difficult for policymakers to effectively manage FDI flows into recipient countries. Besides, the developing countries have much FDI always focus in regions which have low labour cost and rich of natural resources such as Asia and Africa region. However, most of the previous studies use worldwide data without separation into specific continents to clarify the impact and compare territorial differences in research results. In order to further provide more evidence to fix this empirical research gap. Our research will have some new contributions. Firstly, our research results go further than the previous studies by dividing the research data into 3 groups: Asia, Africa, and the full-panel sample. Therefore, our analysis results show a panoramic view and a comparison discussion between continents. Secondly, our research results have the most updated data compared to previous studies. Thirdly, besides the impact of FDI, some macro variables are included in our econometric model to quantitatively estimate the interaction between other economic factors and private investment in recipient economies.

The paper is structured in 5 sections. Section 2 presents an overview of the literature. The econometric methodology and research data are presented in section 3. Next, section 4 shows the estimated results and discussion. Finally, section 5 is conclusions and some policy implications.

\section{Literature Review}

There are some previous studies show a positive impact of FDI on private investment in developing countries. Ndikumana and Verick (2008) note a robust impact of FDI on private investment in Sub-Saharan Africa, this impact is due to the linking and interaction of technological and managerial activities between FDI companies and domestic companies. Cooperative activities can help private investment and private companies more profitable. These results conclude that FDI is a strong catalyst for private investment. So the African countries would have benefited from FDI because this foreign finance can promote private investment by making a high return on capital in the domestic market.

Besides, Adams (2009) studies the impact of FDI on private investment as well as economic growth with a sample of 42 countries in Sub-Saharan Africa in the period 1990-2003. The quantitative results show that FDI has a negative (constraining) effect on private investment in these countries. On the other hand, the lag variable of FDI has a positive effect on private investment. However, the sign and the intensity when adding the regression coefficients of the FDI variable and the lagged FDI variable show a net negative effect. Therefore, the result confirms a crowding-out hypothesis between FDI and private investment in Sub-Saharan Africa countries during the study period.

Agosin and Machado (2005) examine FDI inflows can crowding-in or crowding-out domestic investment in developing countries. The authors develop a theoretical model of investment with a dataset of 36 developing countries in the period of 1971-2000. The results show that in all three developing regions, FDI has the effect of reducing domestic investment, which supports the hypothesis of the crowding-out effect in these regions. This finding requires some urgent policies to make FDI more effective by improving the domestic investment environment in recipient countries.

In another study, Prasanna (2010) investigates an indirect effect of FDI on domestic investment in India in the period of 1991-2007. The author implies that FDI inflows indirectly and positively affect domestic investment by increasing export performance in India. Ang (2010) studies the determinants of private investment in Malaysia. The private investment function is developed from a neoclassical analytical framework with suitable explanatory variables for the Malaysian economy. The result confirms that FDI has an associated effect on private investment (a crowding-in effect). Besides, domestic financial resources have a positive impact on private investment while macro instability (e.g., inflation) has a negative effect on private investment in this economy.

Saglam and Yalta (2011) analysis the impact of FDI on domestic private and public investment in Turkey in 19702009. Their findings indicate that there is no long-term relationship between FDI, public investment and private investment, suggesting a poor contribution of FDI to the 
Turkish domestic investment path. The lack of interaction between FDI and domestic investment hinders the contribution of FDI to economic growth from the capital accumulation channel, which can make a question about the benefits of FDI in Turkey. Djokoto, Srofenyoh, and Gidiglo (2013) explore the relationship between FDI and domestic investment in Ghanaian agriculture in 1976-2011. However, the authors conclude that there is a conflictive point in this relationship, which implies a crowding-out hypothesis in this case study.

Omri and Kahouli (2014) quantitatively estimate the impact of FDI inflows on domestic investment and economic growth in 13 Middle East and North Africa (MENA) countries in 1990-2010. The study results showed that FDI has a positive relationship on domestic investment, which confirms a supporting effect in this region. Besides, the authors suggest that governments should remove more barriers to pave the way for domestic enterprises to access capital, technology, qualifications as well as spillovers knowledge of foreign enterprises.

In the Asian region, Chen, Yao, and Malizard (2017) find that the impact of FDI inflows on Chinese domestic investment is mixed. There are both crowding-in and crowding-out effects found, which depending on the sort of investment of foreign enterprises. In particular, they find that FDI in joint-venture companies has a positive effect on domestic investment, however, when FDI as 100\% foreigninvested companies making a crowding-out effect. The results imply that the Chinese government needs to actively promote domestic capital in investment ventures between FDI and private companies as well as use this way as a catalyst for improving the industries in the economy.

More recently, Jude (2019) study the relationship between FDI and domestic investment in a sample of 10 Central and Eastern European countries in 1995-2015. The author concludes that FDI makes a creative destruction phenomenon in these economies. There are two kinds of the effect of FDI on domestic investment. In detail, FDI has a short-term crowding-out effect on domestic investment, however, followed by a long term crowding-in effect. Tung (2019) analysis the effect of FDI on private investment in Vietnam by a quarterly dataset in 2003-2017. The quantitative result concludes that FDI positively affects private investment not only in the short-run but also in the long-run. The author also suggests that the Vietnamese government should try to balance its international trade balance (because of the trade deficit prolong), which can help to support the private investment in this economy.

\section{Data and Methodology}

Based on previous studies, besides the FDI variable, we conduct to add some independent variables into our econometric model.

Table 1: The list of developing countries in the research sample

\begin{tabular}{|c|c|c|c|c|c|}
\hline Country list & Region & Country list & Region & Country list & Region \\
\hline Azerbaijan & Asia & Uzbekistan & Asia & Mali & Africa \\
\hline Bangladesh & Asia & Benin & Africa & Mozambique & Africa \\
\hline Cambodia & Asia & Burkina Faso & Africa & Malawi & Africa \\
\hline India & Asia & Botswana & Africa & Africa \\
\hline Iran,Islamic Rep. & Asia & Cameroon & Sudan & Africa \\
\hline Jordan & Asia & Congo, Dem. Rep & Africa & Africa \\
\hline Kazakhstan & Asia & Congo, Rep & Africa & Senegal & Africa \\
\hline Lao PDR & Asia & Comoros & Africa & Africa \\
\hline Lebanon & Asia & Mauritius & Africa & Eswatini & Africa \\
\hline Sri Lanka & Asia & Egypt, Arab Rep. & Africa & Africa \\
\hline Mongolia & Asia & Fiji & Africa & Tunisia & Africa \\
\hline Malaysia & Asia & Gabon & Africa & Africa \\
\hline Nepal & Asia & Ghana & Africa & Uganda & Africa \\
\hline Pakistan & Asia & Guinea & Africa & Africa \\
\hline Philippines & Asia & Gambia & Africa & Africa & Africa \\
\hline Thailand & Asia & Guinea-Bissau & Kenya & abwe & \\
\hline
\end{tabular}


Our quantitative research model to study the impact of FDI on private investment in developing countries as follows.

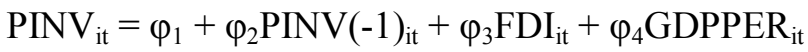
$+\varphi_{5} \mathrm{EDS}_{\mathrm{it}}+\varphi_{6} \mathrm{DC}_{\mathrm{it}}+\varphi_{7} \mathrm{INF}_{\mathrm{it}}+\varphi_{8} \mathrm{LBF}_{\mathrm{it}}+\varphi_{9} \mathrm{ELEC}_{\mathrm{it}}$

$+\varphi_{10} \mathrm{OPENNESS}_{\mathrm{it}}+\varepsilon_{\mathrm{it}}$

Where PINV is the dependent variable denoted by private investment calculated as \% of GDP, besides, $\operatorname{PINV}(-1)$ is the first lag of PINV variable. FDI is the foreign direct investment (unit is \$ billion). GDPPER is GDP per capita calculated as real income per capita (unit is $\$ 1000)$. DC is the domestic credit variable which is calculated as \% of GDP. INF is inflation measured as $\%$ change of consumer price index. EDS is the foreign debt (unit is \$billion). Besides, LBF is labour force which is denoted total number of labour in countries (unit is thousand people), ELEC is percentage of population access to electricity (unit is \%), and OPENNESS is trade openness level of countries, which is calculated by exports plus imports and divide GDP (unit is \%). There are 49 developing countries in our research sample, which is directly collected from the World Bank Indicators database (World Bank, 2019).

Table 1 displays a list of developing countries in the research sample. Table 2 displays descriptive statistics of the variables.

Table 2: Descriptive statistics of the variables

\begin{tabular}{|c|c|c|c|c|c|}
\hline Variable & Mean & Std.Dev. & Min & Max & 54.06 \\
\hline PINV & 15.10 & 7.24 & -4.09 & 55.08 & 1370 \\
\hline FDI & 3.47 & 5.73 & -8.58 & 13.89 & 1370 \\
\hline GDPPER & 1.67 & 2.14 & 0.10 & 513.20 & 1342 \\
\hline EDS & 15.75 & 40.81 & 0.03 & 201.91 & 1370 \\
\hline DC & 38.69 & 39.11 & -79.09 & 5201.94 & 1371 \\
\hline IFL & 48.07 & 743.99 & 0.95 & 100 & 1372 \\
\hline LBF & 177.74 & 613.42 & 0.01 & 220.40 & 1372 \\
\hline ELEC & 48.65 & 35.36 & 34.51 & 11.08 & 1370 \\
\hline
\end{tabular}
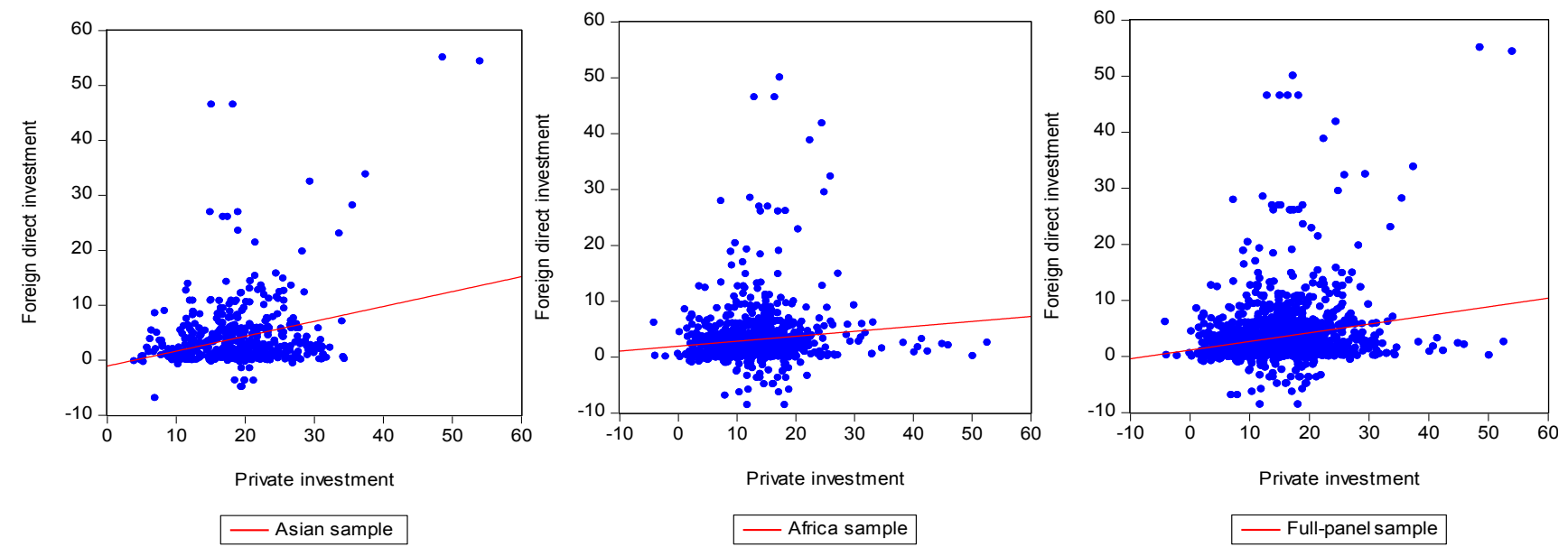

Figure 1: The correlative graphs between FDI and PINV in the samples

To identify the impact of FDI on private investment, the OLS technique is used with two models including the fixed effects model (FEM) and the Random effects model (REM). After that, to choose which is the better one between the fixed effects or the Random effects, we will employ the Hausman test to help the selection. In the case, the null hypothesis is rejected (p-value is smaller 0.05 ), the evidence implies that the REM is biased and the FEM will be chosen, and otherwise.

To have fast predicted results about the impact of FDI on private investment in Asia and Africa region, we have three scatter graphs are drawn following the statistics (see Figure 
1). The vertical axis denotes FDI values and the horizontal axis as the private investment values. The observed results on the graph present clear positive correlations between two variables during the study period. Based on the graphs, we can expect a positive and significant impact of FDI on private investment in estimated results in the next parts.

\section{Results and Discussion}

\subsection{Full-panel Regression}

First of all, we will use the full-panel data (with 49 countries) to estimate the econometric function. Besides, in order to deeply analysis the effect of FDI on private investment in developing countries, we will estimate our econometric function with 4 kinds of models. The different groups of variables help to examine whether there are any changes in sign and statistical significance. Following on our regressive strategy, we will estimate the econometric function with both FEM and REM models. After that, the Hausman test will help us to choose which is the better one. However, all of the Hausman testing results confirm that FEM's results are appropriate because we have Prob $(\mathrm{F}=$ $0.000)<0.05$ in all testing times. So we will present only the results of FEM in the table below (see Table 3 ).

The estimated results show that FDI and other explanatory variables such as $\operatorname{PINV}(-1)$, GDPPER, LBF, OPENNESS, ELEC have a positive effect on PINV, on the other hand, some independent variables including $\mathrm{DC}$, EDS, IFL have a negative impact on PINV.

Table 3: The full-panel estimated result

\begin{tabular}{|c|l|l|l|l|}
\hline Variable & Model 1 & Model 2 & Model 3 & Model 4 \\
\hline PINV(-1) & $0.697^{* * *}$ & $0.700^{* * *}$ & $0.718^{* * *}$ & $0.687^{* * *}$ \\
\hline FDI & $0.069^{* * *}$ & $0.062^{* * *}$ & $0.078^{* * *}$ & $0.065^{* * *}$ \\
\hline IFL & 0.001 & & 0.001 & -0.005 \\
\hline EDS & 0.003 & & & $0.038^{* * *}$ \\
\hline OPENNESS & $0.038^{* * *}$ & $0.031^{* * *}$ & $0.188^{*}$ \\
\hline GDPPER & & $0.162^{*}$ & 0.077 & 0.002 \\
\hline LBF & & 0.001 & 0.001 & -0.007 \\
\hline DC & -0.009 & -0.007 & 0.013 \\
\hline ELEC & & 0.158 & $0.022^{* *}$ & $1.033^{*}$ \\
\hline Constant & $1.725^{* * *}$ & $1.322^{* *}$ & $2.955^{* * *}$ & 0.7426 \\
\hline $\mathrm{R}^{2}$ & 0.7393 & 0.7433 & 0.7573 & 1320 \\
\hline Obs & 1293 & 1320 & 49 & 48 \\
\hline Countries (n) & 48 & 49 & & \\
\hline$* * *$ & & & \\
\hline
\end{tabular}

Notes: $* * *, * * *$ denotes significant at $1 \%, 5 \%$ and $10 \%$

Firstly, the most important result is the sign of the FDI variable. Based on the estimative results, the coefficients of FDI are positive and significant at $1 \%$ in all estimative results, which can help us to conclude that FDI has a positive effect on private investment in developing countries. So the crowding-in effect is confirmed in the case of full-panel data. Our results in line with some previous evidence (e.g., Ndikumana \& Verick, 2008, Ang, 2009; Al-Sadig, 2013; Omri \& Kahouli, 2014). The supporting effect of FDI on PINV can be explained through in the fields of technology transfer (Kobrin, 2005), cooperate in the supply chain or spillovers in management skills (Al-Sadig, 2013). In general, the effect of FDI on PINV is highly appropriate where the value of the estimated coefficient is little changed and significant at $1 \%$ in all regressive models.

Besides, the first lag of private investment, denoted by PINV(-1), has a positive and significant effect on itself in the next period. This is reasonable because it reflects the inertia in the trend of private investment in countries. It can be explained when more private investment in the current year would lead to an increase in the private investment value next year (see Adams, 2009).

In addition, the research results have confirmed that increased economic integration is a good opportunity to raise private investment in developing countries. Specifically, the regressive coefficients of OPENNESS are positive and significant at $1 \%$ in estimative results. Based 
on our findings, the trade openness, as well as contact with the outside, will give businesses many opportunities to have a higher profit level. After that, high profits will use to expand the private investment as well as the private sector of economies. Our finding is supported by some previous studies such as Adams (2009), Al-Sadig (2013), Omri (2014), and Chen, Yao, and Malizard (2017).

Nextly, our results show that GDPPER also has a positive and significant effect on PINV. Following the results, our evidence has confirmed that when income per capita increases, it can support private investment raise accordingly. The increasing of income per capita will be quickly re-invested and expanded to businesses in the private sector, so GDPPER can help to boost PINV in developing countries is reasonable (Ndikumana \& Verick, 2008; Al-Sadig, 2013; Chen, Yao, \& Malizard, 2017; Tung, 2018; Tung, 2019).

Infrastructure is one of the important factors in the development of the private sector as well as the growth of private investment in countries. The access ability to energy is added to represent the infrastructure quality of countries. The ELEC variable has a positive and significant effect on private investment at 5\% (model 3). This evidence implies that the easier to connect to the energy system (through the electricity situation) which can help domestic businesses more efficient in their operations. This finding is also a valuable conclusion because it helps governments can boost private investment through increase access ability to energy.

However, the estimated results also show that the statistical insignificance of the impact of some explanatory variables on private investment including inflation, foreign debt, labour force, and domestic credit. The regressive coefficients are not statistically significant, leading to inconclusive conclusions about the direction of these variables on private investment during the study period. Besides, due to differences between countries (or continents), they maybe make the regression coefficients are not statistically significant. Therefore, we will present the further regressive results with the splitting into Asian and African country groups in order to help the estimated results go deeper with the specificity of the regions.

\subsection{A Comparison between Asia and Africa Regression Results}

In this part, we present the estimated results dividing into two samples, the first one is the Asian developing countries and the second one is the African developing countries. There are four models are estimated as same as the previous part. The regressive results show that there are some different points between the two samples of developing countries (see Table 4).
Our results find that FDI has a positive and significant effect on PINV with all estimative models. So we can conclude that the crowing-in effect is confirmed in both Asian and African developing countries. Besides, we have a new finding that the impact of FDI on private investment in Asia may be much more robust than Africa continental because the coefficients in Asia are higher than Africa. Our result also indicates the FDI is very important with developing countries in Asia and Africa because this foreign financial flow can help support the private investment as well as the private sector. Through support the private businesses, FDI also helps expand the output and provides many employments for the labour market of recipient countries.

The first lagged PINV has a positive and significant impact on the PINV variable, which implies that the private investment is affected by its self. This evidence consists of the full-panel estimations. Following this finding, we can conclude that the trend in investment situation is an important factor relates to private investment in the developing countries. Besides, we find some different points about the role of trade openness (OPENNESS) variable. In detail, the trade openness variable has a positive and significant impact on private investment in African developing countries at $1 \%$ level, however, this effect is not significant in the Asian region. Based on the results, we can conclude that trade openness can help expand the private sector only in the African region. Trade openness allows domestic companies to successfully enter different markets, become more competitive, and thus increase the size of the target markets. So the policymakers in the Asian developing countries need to have some urgent solutions to deal with this problem.

The labour force (LBF) is found to have a positive impact on private investment in Africa, but only statistically significant at $5 \%$ in model 7 . This result shows that a large labour force is not a necessary factor for supporting private investment. In fact, there are many countries have a large population but falling into poverty with the underdeveloped private sector. This evidence leads to a suggestion that the policymakers need to focus to increase labour productivity through improving labour skills (see Al-Sadig, 2013), not related to the quantity of labour.

The domestic credit (DC) variable has a negative and significant effect on private investment in Asian developing countries. This evidence implies that more credit can leads to less in private investment in this region. On the other hand, DC's coefficients have an insignificant impact on private investment in the African region. Besides, the coefficients of the DC variables in Africa are quite small so we can conclude that DC has not got an effect on private investment in the African region. 
The electricity (ELEC) variable has a positive and significant impact on private investment in Asia at 5\% level. This evidence indicates that the available situation of the energy system can support the private sector in the Asia region. However, we can not conclude about the impact of ELEC on PINV in the case of Africa because of the insignificant of estimated results in this region. Finally, we can not conclude about the impact direction of the variable including GDPPER, INF, and EDS because the estimated coefficients are not significant. This problem may be due to restrictions on the number of countries and years used in our research sample.

Table 4: The comparison results of Asia and Africa

\begin{tabular}{|c|c|c|c|c|c|c|c|c|}
\hline \multirow{2}{*}{ Variable } & \multicolumn{2}{|c|}{ Model 5 } & \multicolumn{2}{c|}{ Model 6 } & \multicolumn{2}{c|}{ Model 7 } & \multicolumn{2}{c|}{ Model 8 } \\
\cline { 2 - 8 } & Asia & Africa & Asia & Africa & Asia & Africa & Asia & Africa \\
\hline PINV(-1) & $0.77^{* * *}$ & $0.64^{* * *}$ & $0.76^{* * *}$ & $0.63^{* * *}$ & $0.76^{* * *}$ & $0.68^{* * *}$ & $0.76^{* * *}$ & $0.63^{* * *}$ \\
\hline FDI & $0.07^{* *}$ & $0.05^{*}$ & $0.08^{* * *}$ & $0.04^{*}$ & $0.08^{* * *}$ & $0.07^{* * *}$ & $0.08^{* *}$ & $0.04^{*}$ \\
\hline IFL & -0.01 & 0.01 & & & 0.01 & 0.01 & -0.01 & -0.01 \\
\hline EDS & 0.01 & 0.05 & & & & & -0.01 & 0.01 \\
\hline OPENNESS & 0.01 & $0.06^{* * *}$ & 0.01 & $0.06^{* * *}$ & & & 0.01 & $0.06^{* * *}$ \\
\hline GDPPER & & & 0.12 & 0.23 & 0.11 & 0.19 & 0.15 & 0.21 \\
\hline LBF & & & 0.01 & 0.01 & 0.01 & $0.01 * *$ & 0.01 & 0.01 \\
\hline DC & & & $-0.01^{*}$ & 0.01 & $-0.01^{*}$ & -0.01 & $-0.01^{*}$ & 0.01 \\
\hline ELEC & & & $0.02^{* *}$ & -0.01 & $0.02^{* *}$ & 0.01 & $0.02^{* *}$ & -0.01 \\
\hline Constant & $3.85^{* * *}$ & 0.03 & $2.45^{* * *}$ & -0.27 & $2.64^{* * *}$ & $2.77^{* * *}$ & $2.21^{* *}$ & -0.35 \\
\hline $\mathrm{R}^{2}$ & 0.78 & 0.63 & 0.79 & 0.63 & 0.79 & 0.64 & 0.78 & 0.63 \\
\hline Obs & 459 & 863 & 459 & 863 & 459 & 863 & 459 & 863 \\
\hline Countries & 17 & 32 & 17 & 32 & 17 & 32 & 17 & 32 \\
\hline
\end{tabular}

Notes: $* * *, * * * *$ denotes significant at $1 \%, 5 \%$ and $10 \%$

\section{Conclusions}

For several decades, FDI has been an important role in promoting economic growth in developing countries. However, the impact of FDI on private investment in recipient countries is the subject received many controversies. Our paper aims to study the impact of FDI on private investment with a sample having 49 developing countries in Asia (17 countries) and Africa (32 countries) during the period of 1990-2017. Unlike previous studies, we split the data into three groups for further analysis, including the Asian, African and the full-panel samples.

Our research results show that FDI has a positive and significant impact on PINV in the host countries. So the crowding-in hypothesis is confirmed by our evidence in all estimated results. Besides, the lagged PINV has a positive and significant effect on itself in the next period which reflects the inertia in the trend of private investment in recipient countries. In the full-panel sample, there are some macro factors such as GDPPER, OPENNESS, and ELEC that also have a positive and statistically significant impact on PINV. Besides, when more deeply estimate with smaller samples, we find that trade openness (OPENNESS) and labour force (LBF) have a positive and significant in Africa, on the other hand, not in Asia. However, the domestic credit (DC) variable has a negative and significant effect on private investment only in Asian developing countries. Furthermore, there is only a positive and significant impact of the electricity (ELEC) variable on private investment in Asia.

Following our findings, the policymakers in developing countries need to attract more FDI with various incentives and subsidies policies. The more FDI can lead to increasing in private investment as well as improving the performance of domestic enterprises. Besides, policymakers may be to focus on the supporting policies for private companies because the private investment can help to raise itself in the next period. The relationship between trade openness and private investment is also an issue that policymakers need to pay attention to control. On the other hand, policymakers need to reform the market conditions and support trade liberalization which can implement more aggressively to enhance private investment. Finally, the solutions to improve infrastructure also need to be noted because infrastructure systems is a necessary condition to attract FDI as well as create a good environment business for the development of the private sector as well as private investment in developing countries. 


\section{References}

Adams, S. (2009). Foreign direct investment, domestic investment, and economic growth in Sub-Saharan Africa. Journal of Policy Modeling, 31, 939-949.

Agosin, M. R., \& Machado, R. (2005). Foreign investment in developing countries: Does it crowd in domestic investment? Oxford Development Studies, 33(2), 149-162.

Aitken, B. J., \& Harrison, A. (1999). Do domestic firms benefit from direct foreign investment? Evidence from Venezuela. American Economic Review, 89(3), 605-618.

Ali, A., \& Fei, Y. S. (2016). Impact of Malaysia's Capital Market and Determinants on Economic Growth. Journal of Asian Finance, Economics and Business, 3(2), 5-11. https://doi.org/10.13106/jafeb.2016.vol3.no2.5.

Al-Sadig, A. (2013). The effects of foreign direct investment on private domestic investment: Evidence from developing countries. Empirical Economics, 43, 1-9.

Ang, J. B. (2009). Do public investment and FDI crowd in or crowd out private domestic investment in Malaysia? Applied Economics, 41(7), 913-919.

Borensztein, E. J., Gregorio, D., \& Lee, J. W. (1998). How does FDI affect economic growth?. Journal of International Economics, 45(1), 115-135.

Chen, G. S., Yao, Y., \& Malizard, J. (2017). Does foreign direct investment crowd in or crowd out private domestic investment in China? The effect of entry mode. Economic Modelling, 61, 409-419.

Choi, Y., \& Yüce, A. (2016). Foreign Direct Investment Projects of Korean Companies. Journal of Asian Finance, Economics and Business, 3(1), 5-14. https://doi.org/10.13106/jafeb.2016.vol3.no1.5

Cole, M. A., \& Elliott, R. J. (2005). FDI and the Capital Intensity of "Dirty" Sectors: A Missing Piece of the Pollution Haven Puzzle. Review of Development Economics, 9(4), 530-548.

Djokoto, J. G., Srofenyoh, F. Y., \& Gidiglo, K. (2013). Domestic and foreign direct investment in Ghanaian agriculture. Agricultural Finance Review, 74(3), 427-440.

Erum, N., Hussain, S., \& Yousaf, A. (2016). Foreign Direct Investment and Economic Growth in SAARC Countries. Journal of Asian Finance, Economics and Business, 3(4), 5766. https://doi.org/10.13106/jafeb.2016.vol3.no4.57

Herzer, D., \& Nunnenkamp, P. (2013). Inward and outward FDI and income inequality: Evidence from Europe. Review of World Economics, 149(2), 395-422.

Jude, C. (2019). Does FDI crowd out domestic investment in transition countries?. Economics of Transition and Institutional Change, 27(1), 163-200.

Klein, M., Aaron, C., \& Hadjimichael, B. (2001). Foreign direct investment and poverty reduction (Policy Research Working Paper Series No 2613). World Bank, Washington, DC.

Kobrin, S. J. (2005). The determinants of liberalization of FDI policy in developing countries: 1991-2001. Transnational Corporations, 14(1), 67-103.

Figini, F., \& Görg, H. (2011). Does Foreign Direct Investment Affect Wage Inequality? An Empirical Investigation. The
World Economy, 34(9), 1455-1475.

Fry, M. J. (1993). FDI in a macroeconomic framework: Finance, efficiency, incentives, and distortions (Policy Research Working papers No. 1141). World Bank, Washington, DC.

Ndikumana, L., \& Verick, S., (2008). The Linkages between FDI and Domestic Investment: Unravelling the Developmental Impact of Foreign Investment in Sub-Saharan Africa. Development Policy Review, 26(6), 713-726.

Omri, A., \& Kahouli, B. (2014). The nexus among foreign investment, domestic capital and economic growth: Empirical evidence from the MENA region. Research in Economics, 68(3), 257-263.

Prasanna, N. (2010). Impact of Foreign Direct Investment on Export Performance in India. Journal of Social Sciences, 24(1), 65-71.

Saglam, B. B., \& Yalta, A. Y. (2011). Dynamic Linkages among Foreign Direct Investment, Public Investment and Private Investment: Evidence From Turkey. Applied Econometrics and International Development, 11(2), 71-82.

Szkorupová, Z. (2015). Relationship between Foreign direct investment and domestic investment in selected countries of central and Eastern Europe. Procedia Economics and Finance, 23, 1017-1022.

Tung, L.T. (2018)._The impact of Remittances on Domestic Investment in Developing Countries: Fresh Evidence from the Asia-Pacific Region. Organizations and Markets in Emerging Economies, 9(2), 193-211.

Tung, L.T. (2019). Does Foreign Direct Investment Really Support Private Investment in an Emerging Economy? An Empirical Evidence in Vietnam. Montenegrin Journal of Economics, 15(1), 7-20.

Ucal, M. S. (2014). Panel data analysis of foreign direct investment and poverty from the perspective of developing countries. Procedia - Social and Behaviour Sciences, 108, 1101-1105.

UNCTAD. (2018). World Investment Report: Investment and New Industrial Policies. United Nations, Geneva.

Wang, D. T., Gu, F. F., Tse, D. K., \& Yim, C. K. (2013). When does FDI matter? The roles of local institutions and ethnic origins of FDI. International Business Review, 22(2), 450 465 .

Wang, M. (2010). Foreign direct investment and domestic investment in the host country: evidence from panel study. Applied Economics, 42(29), 3711- 3721.

World Bank. (2019). World Development Indicators online database. (May/2019). Washington, DC. Retrieved May 15, 2019, from http://data.worldbank.org/indicator.

Wu, G., Sun, Y., \& Li, Z. (2010). The crowding-in and crowdingOut effects of FDI on domestic investment in the Yangtze delta region. Transnational Corporations Review, 10(2), 5979.

$\mathrm{Xu}$, G., \& Wang, R. (2007). The effect of foreign direct investment on domestic capital formation, trade, and economic growth in a transition economy: evidence from China. Global Economy Journal, 7(2), 1-21. 